\title{
Innovation of Service Quality in City Bus Transportation
}

\author{
Kristina Setyowati \\ Public Administration Departement \\ Sebelas Maret University \\ (krist_uns@yahoo.co.id)
}

\begin{abstract}
The existence of city bus public transportation is very important and desirable to those having no transportation vehicle or incapable of riding their own vehicle. The objective of research was to find out the innovation of service quality in public transportation particularly city bus in Surakarta. The research method was mix method with Exploratory Sequential strategy. The study on the innovation of service quality through partnership was analyzed using qualitative method, while service quality using statistic descriptive by considering five dimensions of quality (Reliability, Accessibility, Comfortable, Assurance and Tangible, totally 14 attributes). Technique of analyzing data used was Importance and Performance. The result of research showed that through partnership in managing city bus, service quality of city bus public transportation had been good, because 6 attributes were in $B$ quadrant, in which there was a high compatibility between user expectation and service performance.
\end{abstract}

Keywords-Public Transportation; Service Quality; Partnership

\section{INTRODUCTION}

Public transportation, particularly urban public transportation plays a very important role in catering to urban transportation and facilitating the society to run its activity in all of different locations in urban areas. The existence of urban public transportation is very desirable particularly to those having no private transportation vehicle or incapable of riding their own vehicles.

Regarding this, Nugroho and Octo (20071 confirmed that "Even the most advanced city must need public transportation to meet its society's mobility need. Most urban people in big cities in Indonesia are still dependent on public transportation. It is because of many people with lower-middle economic level unlikely to have vehicle individually

Republic of Indonesia's Law Number 22 of 2009 about Traffic and Road Transportation in article 7 (1) mentions that: "the organization of traffic and road transportation in direct service activity to community is conducted by government, local government, enterprise, and/or society". It means that road transportation/public transportation service provisions is the responsibility of government/local government. The availability of comprehensive public transportation will highly affect a city's mobility.
Public transportation problems in big cities, including Yogyakarta, as suggested in Munawar's (2007)2 study, are as follows:

(a) overall inadequate capacity; (b) poor quality and choice; (c) severe traffic jam; (d) seizure of bus stop by street vendor; (e) limited fund for reforming and repairing vehicles; (f) rigid and complexity regulation frame currently, $(\mathrm{g})$ bus sector fragmentation; (h) ineffective legal and administrative structures. And in fact, the comfort and quality of public transportation fleets is low because many vehicles have been rotten and dirty, and many public transportation vehicles are small and low in capacity.

The condition of service quality in city bus public transportation in Surakarta is not far different from that in other big cities. The quality of public transportation (particularly City Bus) in Surakarta degrades over times and less is accessible with disorganized route condition, limited road infrastructure (capacity), and increasingly uncontrolled number of private vehicles (particularly motorcycle). Meanwhile the service performance of city bus, viewed from load factor, cannot reach $100 \%$ (only $60-70 \%$ ), with headway reaching 10 minutes, less feasible bus, so that the users abandon it. The explanation above represents the dull portrait of transportation in cities in general, in which people finally prefer using their own vehicle to utilizing public transport. Such the condition generates state of the art that "public transportation has been public choice to transit".

The efficiency and effectiveness of public service, particularly city buse transportation service, becomes the government's responsibility to improve service quality of public transportation. In this position, government policy is very meaningful. But on the other hand, government still faces problem of limited fund source. It is in this framework that the development is inhibited, including in public service development. Dwiyanto (2008)3 stated: "through governance approach and decentralization movement, the government is defined not only as an institution but also as governing process implemented in partnership between governmental, semigovernmental and non-governmental institutions such as NGO and private institutions running in balanced and multidirectional manner".

The definition of partnership, according to Savas (200)4, Rondinelli (2002)5, Bovaird (2004)6, Grimsey \& Lewis 
(2004)7, Glasbergen (2007)8 and according to Stiglitz, (in Dwiyanto, 2010)9 is: the involvement of private and other non-governmental institution in public service management will provide many benefits.

Firstly, the involvement of private can be an alternative organization of public service. Public service has very broad scope and is unlikely to be organized by government alone because it also faces limited budget. For that reason, the private involvement is a certainty to cope with government's limitation.

Secondly, the involvement of private can results in the more varying public service responsive to the society's need. The private is usually more responsive and more sensitive to the quality the society needs.

Thirdly, the involvement of private is important to encourage the improvement of competition in bureaucratic service performance.

Meanwhile, the study on partnership in transportation has been conducted, among others, by Decoria, Patrict (2005)10, Schneider and Davis, 2006)11, Lindau, Luis Antonio, et.al. (2007)12, and Tilahun \& Gitau (2010)13 finding that a publicprivate transportation partnership "is a contractual agreement between public or government institutions and private entity facilitating in providing and operating the facility of project infrastructure or service.

Thus, it can be said that partnership in improving the service quality of transportation makes the service scope broader, more responsive, and encourages the improvement of service quality.

Meanwhile, the definition of transportation, according to Miro (2005)14, is "an activity of displacing, moving, carrying or transferring an object, either human being or good from one place to another". Meanwhile, according to Salim (2008)15, transportation is "an activity of moving good (luggage) and passenger from one place to another". In transportation, there are two important elements: (1) movement, and (2) physically, changing passenger's or good's place into another one.

To ensure the organization of transportation service, A Communication Minister's Regulation Number 49 of 2005 is developed about National Transportation System (SISTRANAS). The goal and objective of its development is "to make Sistranas document a guideline to transportation regulation and development, in order to achieve an effective and efficient national transportation.

Regarding service quality, some scholars such as Crosby (1979)17, Gaspersz, (2001), and Ducker, 1991 (in Aykac, et.al: 2009) 18 defined service quality as "what the customers receive with their willingness to pay what the supplier gives". For that reasons, service quality is often "conceptualized as the comparison between service expectation and perceived actual performance"

Service Quality, according to Edvardsson (1998) in Zisis, Pandelis et.al, 2009), is defines as "the attempt taken by organization to meet expectation and precondition to anticipate customer expectation. Thus, service quality is approached as "customer-oriented".
This study measures service quality using SERVQUAL method developed by Parasuraman, Zeithaml, and Barry, (1997)18. The model builds on the comparison of two main factors: customers' perception on the actual service they receive (perceived service) and the service they want or expected (expected service). It can be said that service quality can be seen from five (5) dimensions in which company/organization can choose combination of those five dimensions. They are: Reliability, Responsiveness, Assurance, Empathy and tangibles.

Regarding transportation service, TRB (1999) mentioned that there are some service quality aspects in public transportation: reliability, responsiveness, competency, access, decorum, communication, credibility, security, understanding and tangible, public transport availability, overseeing, stakeholders, travelling time, safety, security, treatment, infrastructure, economic, and capacity.

In this study, to measure the service quality of city bus public transportation, five (5) dimensions were used: 1) reliability including: (a) timeliness, (b) speed, and (c) waiting time attributes; 2) accessibility encompassing: (a) accessibility, (b) affordable tariff, and (c) accessibility to difable (those with different ability); 3) tangible encompassing: fleet number, fleet condition, bus stop number; 4) comfortable including comfort inside bus, not crowded, AC availability, no street musician, and 5) assurance including feeling of secure with the way the driver drives, and no pickpocket.

\section{METHOD}

This study employed mixed method with exploratory sequential strategy, meaning that this study focused on the exploratory analysis on qualitative data to analyze the partnership phenomenon as the step in innovating service quality. Furthermore, to measure quality, a quantitative method was used with Importance and Performance Analysis technique suggested for the first time by Martilla and James (1977) and Cartesian Chart (Rangkuti: 2006) ${ }^{19}$ stating that there are 4 quadrants: Quadrant A (attributes to improve )/Main priority, Quadrant B (maintain performance), Quadrant C (attributes to maintain)/ Low Priority. Quadrant D (main to priority) / Superfluous.

\section{RESUlT AND DISCUSSION}

One of innovations in improving Service Quality of public transportation in Surakarta has been conducted by Surakarta City Government (in this case Transportation and Communication and Information Service) through a partnership with PT. Bengawan Solo Trans. The government serves as facilitator and regulator in transportation service area (issuing route license, providing transportation infrastructure, APILL, bus stop, and traffic sign), while PT. Bengawan Solo Trans along with Surakarta City Government provides its transportation fleet through Contract. In this model, the government establishes public policy, while private company serves as service provider (producer), and community serves as consumer that should pay for the public 
service. The availability of new fleet and service management is expected to improve service quality of public transportation.

To find out the improvement/condition of service quality due to the innovation in the attempt of improving service quality through partnership, an analysis on service quality was conducted with Importance and Performance Analysis and Cartesian chart in five dimensions (Reliability, accessibility, conformable, assurance dan Tangible including 14 indicators), and the analysis found that there are 6 indicators on quadrant B: timeliness, accessibility to difable, short waiting time, accessibility, fleet number, seating capacity, and $\mathrm{AC}$ availability). It means that the 6 indicators are in high customer expectation position and the service quality perform given is high and its service performance should be maintained because it is highly expected by the customers.

\section{CONCLUSION}

Considering the data analysis, it can be concluded that innovation the Surakarta city government has implemented through partnership between Dishubkominfo (Transportation, Communication and Information Service) and PT. Bengawan Solo Trans with contract model can improve the service quality of public transportation, as indicated with 6 (six) indicators of service quality existing in quadrant $\mathrm{B}$, in which this B quadrant is the position where the customer expectation is high and service performance is high as well, meaning that service quality of public transportation in Surakarta City has been good.

\section{REFERENCES}

[1] Nugroho, Harimurti dan Okto Risdianto, 2007, "Model Rute Angkutan Umum Penumpang Dengan Aplikasi Sistem Informasi Geografis (SIG) (Studi Kasus Kota Semarang ), “ Jurnal Tata Loka , Volume 9 Number 4, November 2007.

[2] Munawar, Ahmad, 2007, Public Transport Reformin Indonesia, A Chase Study in The City of Yogyakarta, http://www.google.co.id/\#hl=id\&sugexp=frgbld\&gs_nf=1\&pq=public transport reform in indonesia -ahmad munawar\&cp $=12 \& g s$ id $=\mathrm{ub} \& \mathrm{xhr}=\mathrm{t} \& \mathrm{q}=$ Penelitian Public transport Reform in Indonesia - (accessed on November 15, 2011.

[3] Dwiyanto, Agus, (ed), 2008, Mewujudkan Good Governance Melalui Pelayanan Publik, Gajah Mada University Press, Yogyakarta.

[4] Savas, E. S. 2000. Privatization and Public Private Partnership. Chatham House Publisher, Seven Bridges Press.LLC, New York- London.

[5] Rondinelli, D.A \& Cheema, G.S, 1983, "Implementing Decentralization Policies: an Introduction ", in Cheema, G.S \& Rondinelli,D.A (ed). Decentralization and Development: Policy Implementation in Developing Countries, Sage Publication, Beverly Hills, California.

[6] Bovaid, Tony, 2004, "Public -Private Partnership : From Contested Concept to Prevalent Practice", International Review of Administrative Sceinces, 70, (2) p. 199-215.

[7] Grimsey, Darrin and Mervyn K. Lewis, 2004, Public Private Partnership : The Worldwide Revolution in Infrastructure Provision and Project Finance, Edward Elgar, Cheltenham, UK, Northampton, MA, USA.

[8] Glasbergen, Pieter; Bierman, Frank; Mol, Arthur P.J, 2007, Partnership Governance and Sustainable Development : Reflection on Theory and Practice, Edward Elgar, Chaltenham, UK, USA.

[9] Dwiyanto, Agus, 2010. Manajemen Pelayanan Publik: Peduli, Inklusif, dan Kolaboratif. Gajah Mada University Press. Yogyakarta
[10] Decoria, Patrick-Sauza, 2005, "Inovative Public-Private Partnership Models for Road Pricing/BRT Initiatives", Journal of Public Transportation, Vol.8 No.1 of 2005, pp.57-78

[11] $\neg \neg$ Schneider, Michael and Davis,jonathon Public Private Partnership in Public Transportation Policies and Principles for the Transit Industry, ( American Public Transportation Association Task Force on Public Private Parnership http:/www/hcppp.org/publiction/transit denver0806/APTA_Rountable white paper_080612.pdf

[12] Lindau, Luis Antonio; Dos Santos Senna, Luiz Afonso.; Strambi, Orlando, dan Martins, Wagner Colombini. 2007. "Developing Bus Rapit Transit (BRT) System in Brazil: Through Public Private Partnership. http://www.thredbo-conference-series.org/downloads/thredbo10_papers thredbo10-plenary

[13] Tilahun, Nebiyoua Y. dan Levinson, David M. 2010. "A Moment of Time: Reliability in Route Choice Using Stated Preference”. Journal of Intelligent Transportation Systems, 14 (3):179-187.

[14] Miro, Fidel. 2005. Perencanaan Transportasi. Erlangga. Jakarta

[15] Salim, Abas, H. A. 2008. Manajemen Transportasi. Raja Grafindo Perkasa. Jakarta

[16] Crosby. P.B. 1979, Quality Is Free: The art of Making Quality Certain, New York : McGraw-Hill

[17] Aykac, Aydyn, Ates, Cetin, 2009, "Effects of Service Quality on Customer Satisfaction and Customer Loyalty: Marmara University Hospital", International Congress on Performance and Quality in Health (Uluslararasi Saglikta Performans ve Kalite Kongresi), March 19-21, 2009, Antalya, Turkey (http://ssrn.com.abstract/ 1362601

[18] Parasuraman, Zeithaml and Berry, 1997, "A Conceptual Model of Services Quality and Its Implications for Future Research, Journal of Marketing, Vol.49. Autumn (1997:219)

[19] Rangkuti, Freddy, 2006, Measuring Customer Satisfaction, Gramedia Pustaka Utama, Jakarta. 